\title{
UJI PENGARUH SALIVA BUATAN TERHADAP KEKUATAN TEKAN SEMEN IONOMER KACA TIPE II YANG DIRENDAM DALAM MINUMAN ISOTONIK
}

\author{
${ }^{1}$ Dwi Cahya Fitriyana \\ ${ }^{2}$ D.H.C. Pangemanan \\ ${ }^{3}$ Juliatri \\ ${ }^{1}$ Mahasiswa Program Studi Pendidikan Dokter Gigi Fakultas Kedokteran \\ Universitas Sam Ratulangi Manado \\ ${ }^{2}$ Fakultas Kedokteran Universitas Sam Ratulangi Manado \\ ${ }^{3}$ Program Studi Pendidikan Dokter Gigi Fakultas Kedokteran \\ Universitas Sam Ratulangi Manado \\ Email: dwicahya_ia1sa@yahoo.co.id
}

\begin{abstract}
Abstrak: Perendaman SIK tipe II dalam minuman asam seperti minuman isotonik dapat mengurangi kekuatan tekan SIK tipe II. Hal ini disebabkan proses degradasi matriks SIK pada kondisi asam. Namun di sisi lain, saliva buatan yang dapat menetralkan kondisi ini. Tujuan: untuk untuk mengetahui pengaruh saliva buatan terhadap kekuatan tekan SIK yang direndam dalam minuman isotonik. Metode: Spesimen SIK tipe II berukuran $6 \mathrm{~mm}$ x $6 \mathrm{~mm}$ x $12 \mathrm{~mm}$ (panjang $\mathrm{x}$ lebar $\mathrm{x}$ tinggi) direndam selama 24 jam dalam air, 24 jam di dalam minuman isotonik, 24 jam di dalam minuman isotonik dan lanjutkan dengan 72 jam pada saliva buatan, 48 jam di minuman isotonik, dan 48 jam di minum isotonik dan lanjutkan dengan 144 jam dalam saliva buatan. Kekuatan tekan diukur menggunakan Universal Testing Machine dengan kecepatan 0,5 mm / min. Analisis statistik dilakukan dengan one-way ANOVA dan post-hoc uji $L S D(\alpha=0,05)$. Hasil: Uji statistik menunjukkan perbedaan yang signifikan dari kekuatan tekan $(\mathrm{p}<0,05)$. Simpulan: terdapat pengaruh saliva buatan terhadap kekuatan tekan SIK tipe II yang direndam dalam minuman isotonik.
\end{abstract}

Kata kunci: minuman isotonik, saliva buatan, kekuatan tekan, Semen Ionomer Kaca tipe II.

\begin{abstract}
The immersion of GIC type II in acid drink like isotonic drink could reduce the compressive strength (CS) of GIC type II. This is due to the matrix degradation process of GIC in acid condition. But on the other hand, there is artificial saliva that can neutralize this condition. Purpose: Purpose of this study was to evaluate the effect of artificial saliva on compressive strength of GIC type II immersed in isotonic drink. Method: The GIC specimens of $6 \mathrm{~mm} \times 6 \mathrm{~mm} \times 12 \mathrm{~mm}$ (length $\mathrm{x}$ width $\mathrm{x}$ depth) were immersed for 24 hours in water, 24 hours in isotonic drink, 24 hours in isotonic drink and continue with 72 hours in artificial saliva, 48 hours in isotonic drink, and 48 hours in isotonic drink and continue with 144 hours in artificial saliva. The compressive strength was determined using Universal Testing Machine with a crosshead speed of $0.5 \mathrm{~mm} / \mathrm{min}$. Statistical analysis was performed by one-way ANOVA and post-hoc LSD test $(\alpha=0.05)$. Result: Statistic test shows significant difference of CS $(p<0,05)$. Conclusion: conclusion of this study artificial saliva gives effect to the rising of the compressive strength of GIC type II immersed in isotonic drink.
\end{abstract}

Keywords: Isotonic drink, artificial saliva, compressive strength, Glass Ionomer Cement type II. 
Semen Ionomer Kaca (SIK) merupakan bahan restorasi yang terus dikembangkan dan banyak digunakan oleh dokter gigi. SIK pertama kali diperkenalkan oleh Wilson dan Kent pada tahun 1971 yang merupakan gabungan dari semen silikat dan semen polikarboksilat. $^{1,2}$ Terdapat beberapa jenis SIK berdasarkan penggunaannya, yaitu tipe I untuk material perekat, tipe II untuk material restorasi dan tipe III untuk basis atau pelapis. ${ }^{3,4}$ SIK sering disebut Alumine Silicate and Polyacrylic Acid (ASPA). Ukuran partikel gelas SIK bervariasi, yaitu sekitar 50 um sebagai bahan restorasi dan sekitar 20 um sebagai bahan pelapis. ${ }^{5,6}$

Kemasan SIK konvensional terdiri dari powder dan liquid dapat dilihat pada gambar 2. Powder SIK merupakan kaca kalsium fluoroaluminuslikat yang larut dalam liquid asam. Kandungan powder SIK komersial ialah silikat $\left(\mathrm{SiO}_{2}\right)$, aluminium $\left(\mathrm{Al}_{2} \mathrm{O}_{3}\right)$, aluminium fluoride $\left(\mathrm{AlF}_{3}\right)$, kalsium fluoride $\left(\mathrm{CaFa}_{2}\right)$, natrium fluoride $(\mathrm{NaF})$, dan aluminium fosfat $\left(\mathrm{AlPO}_{4}\right)$. Material dasar ini digabung sehingga membentuk kaca yang seragam dengan cara dipanaskan sampai suhu $1100-1500^{\circ} \mathrm{C}$ Lanthanum, srosium barium, dan oksida seng ditambahkan untuk mendapatkan sifat radioopak. Liquid untuk SIK adalah larutan dari asam poliakrilat 40$50 \%{ }^{7,8}$

Sifat utama SIK yaitu kemampuannya untuk melekat pada email dan dentin tanpa adanya penyusutan atau panas yang bermakna, mempunyai sifat biokompatibilitas dengan jaringan periodontal dan pulpa, pelepasan fluor yang bereaksi sebagai antimikroba dan kariostatik, kontraksi volume pada pengerasan sedikit, dan koefisien ekspansi termal sama dengan struktur gigi. ${ }^{9,10}$ Sifat SIK cukup keras tetapi rapuh, kekuatan tekan relatif tinggi tetapi daya tahan terhadap fraktur dan keausan rendah, sehingga tidak digunakan untuk merestorasi gigi posterior dengan beban kunyah besar. Daya tahan yang rendah terhadap keausan dipengaruhi oleh sifat kekerasan permukaan. ${ }^{6}$

Dalam penelitian $\mathrm{Xu}$ et al yang mengukur kemampuan bahan restorasi SIK dalam melepaskan ion fluor terhadap compressive strength, menyimpulkan bahwa terjadi korelasi negatif antara pelepasan ion fluoride dengan compressive strength. Bahan material yang memiliki tingkat pelepasan ion fluoride lebih tinggi, secara umum mempunyai kekuatan lebih rendah dari material yang memiliki tingkat pelepasan ion fluoride rendah. ${ }^{11}$ Compressive strength SIK konvensional umumnya ialah 150 Mpa. Nilai ini menunjukkan bahwa SIK cukup mampu menahan tekanan oklusal, namun masih tergolong rendah. ${ }^{1}$

Sumber minuman asam yang banyak dikonsumsi masyarakat umum di antaranya ialah minuman isotonik. Jumlah konsumsi minuman isotonik di Indonesia sudah mencapai 200 juata liter pertahun. ${ }^{12}$ Minuman isotonik mengandung sukrosa yang terbukti menurunkan $\mathrm{pH}$ plak dan memproduksi asam. Level asam yang sangat tinggi bertujuan untuk menambah rasa dan meningkatkan ketahanan produk. Konsumsi minuman isotonik terus meningkat dari tahun ke tahun. Pada tahun 2005, Australian Food News melaporkan bahwa konsumsi minuman isotonik global meningkat 10\% dari tahun sebelumnya menjadi 9.700 juta liter. Pada tahun 2007, konsumsi minuman isotonik meningkat 5,9\% dari tahun 2006 menjadi 11.582 juta liter. $^{14}$ Minuman isotonik memiliki $\mathrm{pH}$ antara 2,4-4,5, yaitu berada di bawah batas $\mathrm{pH}$ kritis. ${ }^{13}$

Saliva memiliki beberapa fungsi di antaranya untuk lubrikasi jaringan dalam rongga mulut agar tidak terjadi abrasi saat mastikasi berlangsung, membantu metabolisme karbohidrat, aktivitas antibakteri terhadap bakteri patogen rongga mulut, turut membantu mempertahankan kestabilan sistem buffer dalam rongga mulut. ${ }^{14,15}$ Saliva ikut berperan saat interaksi antara SIK dengan minuman isotonik pada rongga mulut. Saliva memiliki kemampuan buffer yang menetralisir keasaman dan juga fungsi pembilasan untuk mengurangi lamanya kontak antara minuman isotonik dengan SIK. ${ }^{13}$

\section{BAHAN DAN METODE}

Penelitian ini merupakan penelitian eksperimental laboratorium in vitro dengan menggunakan Post Test Only Control Group 
Fitriyana, Pangemanan, Juliatri; Pengaruh Saliva Buatan Terhadap...

Design. Tempat penelitian ini dilaksanakan di Laboratorium Kimia Fakultas MIPA dan Laboratorium Struktur dan Material Bangunan Fakultas Teknik Universitas Sam Ratulangi Manado pada bulan Juni 2014.

Penelitian ini menggunakan spesimen SIK tipe II berbentuk balok dengan ukuran $6 \mathrm{~mm}$ x $6 \mathrm{mmx} 12 \mathrm{~mm}$ (panjang x lebar x tinggi) yang dicetak menggunakan cetakan aluminium, permukaannya padat dan tidak berporus. Selanjutnya spesimen ini dibagi dalam lima kelompok berdasarkan perlakuan perendamannya, yaitu di dalam air selama 24 jam, di dalam minuman isotonik selama 24 jam, di dalam minuman isotonik selama 24 jam lalu dilanjutkan di dalam saliva buatan selama 72 jam, di dalam minuman isotonik selama $48 \mathrm{jam}$, dan yang terakhir di dalam minuman isotonik selama 48 jam lalu dilanjutkan di dalam saliva buatan selama 144 jam. Semua spesimen yang selesai dibuat, direndam terlebih dahulu di dalam akuabides selama 24 jam, dan disimpan dalam incubator. Untuk kelompok perendaman dalam air selama 24 jam, setelah direndam spesimen dikeringkan dengan tissue, lalu dilakukan uji kekuatan tekan. Sedangkan kelompok lainnya langsung dilakukan perendaman sesuai dengan perlakuan masing-masing. Kelompok spesimen dengan perlakuan lanjutan perendaman di dalam saliva buatan, setelah dilakukan perendaman di dalam minuman Gatorade dan dibilas dengan akuabides, selanjutnya dilakukan perendaman di dalam saliva buatan. Kelompok yang sudah selesai mendapat perlakuan dilakukan uji kekuatan tekan menggunakan Universal Testing Machine Shimadzu Autograph AG 5000 E dengan crosshead speed $0.5 \mathrm{~mm} / \mathrm{menit}$ dan Load $250 \mathrm{KgF}$. Data hasil penelitian ditabulasi, kemudian dilakukan analisis statistik menggunakan Statistical Product and Service Solution (SPSS) yaitu dengan uji One-Way ANOVA dilanjutkan dengan uji post-hoc LDS.

\section{HASIL PENELITIAN}

Nilai rerata kekuatan tekan SIK konvensional tipe II dan standar deviasi dapat dilihat pada Tabel 1.

Tabel 1. Rerata dan standar deviasi kekuatan tekan SIK tipe II (Mpa)

\begin{tabular}{|c|c|c|}
\hline Kelompok Perendaman & $\mathrm{n}$ & $\bar{x} \pm \mathrm{SD}$ \\
\hline Air 24 jam & 3 & $29,47 \pm 2,46$ \\
\hline Isotonik 24 jam & 3 & $24,96 \pm 2,56$ \\
\hline $\begin{array}{l}\text { Isotonik } 24 \text { jam dan saliva } \\
\text { buatan } 72 \text { jam }\end{array}$ & 3 & $31,92 \pm 1,2$ \\
\hline Isotonik 48 jam & 3 & $27,42 \pm 1,8$ \\
\hline $\begin{array}{l}\text { Isotonik } 48 \text { jam dan saliva } \\
\text { buatan } 144 \text { jam }\end{array}$ & 3 & $40,11 \pm 6,30$ \\
\hline
\end{tabular}

Kelompok perendaman isotonik 48 jam dilanjutkan saliva buatan 144 jam menunjukkan nilai rerata kekuatan tekan paling tinggi yaitu 40,11 Mpa. Kelompok perendaman isotonik 24 jam menunjukkan rerata nilai kekuatan tekan paling rendah yaitu 24,96 Mpa. Dua kelompok perendaman yang mendapatkan perlakuan awal direndam di dalam minuman isotonik, lalu berikutnya direndam dalam saliva buatan, keduanya menunjukkan kenaikkan nilai kekuatan tekan.

Probabilitas normalitas semua kelompok mempunyai distribusi normal, karena didapatkan probabilitas normalitas lebih dari 0,05 yaitu $0,082(\mathrm{p}>0,05)$. Setelah diketahui semua kelompok mempunyai distribusi normal, maka untuk mengetahui adanya perbedaan kekuatan tekan SIK Konvensional tipe II antar kelompok perlakuan secara statistik, dilakukan uji parametik One-way ANOVA dengan taraf kemaknaan 5\%. Hasil uji ANOVA didapatkan probabilitas $0,003 \quad(\mathrm{p}<0,05)$, maka berarti ada perbedaan bermakna antar kelompok yang diuji.

Penentuan perbedaan kemaknaan antar kelompok, dilakukan dengan uji post-hoc $L S D$ pada $\alpha=0,05$ yang dapat dilihat pada tabel 2. Kelompok perendaman yang bermakna adalah yang mempunyai signifikansi kurang dari 0,05 $(\mathrm{p}<0,05)$. 
Jurnal e-GiGi (eG), Volume 2, Nomor 2, Juli-Desember 2014

Tabel 2. Uji post-hoc LSD kekuatan tekan SIK tipe II

\begin{tabular}{|c|c|c|c|c|c|}
\hline $\begin{array}{l}\text { Kelompok } \\
\text { Perendaman }\end{array}$ & $\begin{array}{l}\text { Air } 24 \\
\text { jam }\end{array}$ & $\begin{array}{l}\text { Isotonik } \\
24 \text { jam }\end{array}$ & $\begin{array}{l}\text { Isotonik } 24 \text { jam dan } \\
\text { saliva buatan } 72 \text { jam }\end{array}$ & $\begin{array}{l}\text { Isotonik } \\
48 \text { jam }\end{array}$ & $\begin{array}{l}\text { Isotonik } 48 \text { jam dan } \\
\text { saliva buatan } 144 \text { jam }\end{array}$ \\
\hline Air 24 jam & - & & & & \\
\hline Isotonik 24 jam & 0,134 & - & & & \\
\hline $\begin{array}{l}\text { Isotonik } 24 \text { jam dan } \\
\text { saliva buatan } 72 \text { jam }\end{array}$ & 0,395 & $0.031^{*}$ & - & & \\
\hline Isotonik 48 jam & 0,476 & 0,395 & 0,134 & - & \\
\hline $\begin{array}{l}\text { Isotonik } 48 \text { jam dan } \\
\text { saliva buatan } 144 \text { jam }\end{array}$ & $0,003^{*}$ & $0,00^{*}$ & $0,014^{*}$ & $0,001^{*}$ & - \\
\hline
\end{tabular}

Keterangan: * = bermakna

\section{BAHASAN}

Lama waktu dalam penelitian ini yaitu 24 jam dan 48 jam untuk perendaman dalam minuman isotonik, hal ini didasarkan pada 3 menit jumlah lama waktu terpaparnya gigi dan bahan tumpatan dengan minuman yang dikonsumsi dalam setiap gelas/hari. Jadi interpretasi waktu dalam penelitian ini dapat menggambarkan konsumsi minuman isotonik yaitu 24 jam sama dengan 20 bulan dan 48 jam dapat menggambarkan konsumsi minuman selama 40 bulan. Untuk waktu perendaman dalam saliva buatan yaitu 72 jam dan 144 jam, hal ini didasarkan pada waktu pembilasan oleh saliva dalam rongga mulut biasanya berlangsung lebih lama dari waktu terpaparnya gigi dan bahan tumpatan. $^{16}$

Berdasarkan hasil penelitian ini perbedaan nilai kekuatan tekan yang tidak bermakna antara perendaman dalam air dengan kelompok perendaman di dalam minuman isotonik 24 jam dan 48 jam, kemungkinan sehubungan dengan $\mathrm{pH}$ asam dari minuman isotonik, sehingga ion $\mathrm{H}^{+}$dari isotonik bereaksi dengan gugus polycarboxilat salt pada ujung matriks SIK. Gugus polycarboxilat salt yang berikatan dengan dengan ion $\mathrm{H}^{+}$akan terputus dari polimer, sehingga terbentuk monomer sisa, proses inilah yang disebut degradasi matriks SIK. ${ }^{17}$

Perendaman di dalam air memiliki efek tambahan pada SIK tipe II. Air akan diserap oleh semen dan disimpan dalam matriks, apabila melebihi kapasitas polimer akibatnya akan terjadi ekspansi. Perendaman yang terlalu lama membuat monomer yang tidak bereaksi (residual) akan bermigrasi keluar, sehingga membentuk ruang kosong yang akan diisi oleh molekul air menyebabkan penurunan kekuatan tekan. Pada beberapa penelitian sebelumnya air digunakan sebagai variabel kontrol dan pada penelitian tersebut tidak terjadi perubahan kekuatan tekan SIK (sesuai kekuatan strandar bahan tumpat SIK $76 \mathrm{Mpa}$ ). Berbeda dengan penelitian ini yang terjadi perubahan pada air yang digunakan sebagai kontrol dengan rata-rata kekuatan tekan SIK ialah 29,47 Mpa. ${ }^{18,19}$

Perendaman di dalam minuman isotonik selama 48 jam dibandingkan dengan perendaman di dalam minuman isotonik selama 24 jam menunjukkan peningkatan nilai kekuatan tekan yang tidak bermakna. Hal ini kemungkinan berkaitan dengan reaksi pengerasan, sehingga ikatan antar matriks polycarboxilate salt dan aluminosilicate glass mendapatkan waktu untuk terbentuk kembali. Proses polimerisasi akan tetap berlangsung setelah reaksi pengerasan. Selain itu, pada SIK tipe II yang sudah terpolimerisasi dengan sempurna, monomer sisanya akan sulit untuk bereaksi kembali. ${ }^{12}$

Makanan dan minuman yang mengandung asam salah satunya minuman isotonik dapat menyebabkan erosi, karena berada antara rentan nilai pH 2,4-4,5. Berdasarkan hasil penelitian sebelumnya oleh oleh Patel, diketahui bahwa minuman dengan kandungan asam tinggi mempunyai pengaruh terhadap kelarutan fosfat yang merupakan 
Fitriyana, Pangemanan, Juliatri; Pengaruh Saliva Buatan Terhadap...

awal demineralisasi, salah satu tanda demineralisasi ialah larutnya berbagai mineral, utamanya kalsium dan fosfat. ${ }^{20}$

Hasil penelitian tersebut sejalan dengan pernyataan Mettler yang mengatakan bahwa minuman isotonik dapat mengikis permukaan gigi dan dapat menyebabkan demineralisasi, maka dampaknya pada tumpatan juga diduga akan lebih besar. Beberapa penelitian membuktikan bahwa minuman isotonik biasanya di munium secara perlahan, sehingga sisa-sisa residu minuman ini dapat tertinggal dalam rongga mulut untuk beberapa menit, karena minuman isotonik mempunyai $\mathrm{pH}$ yang rendah yaitu $\mathrm{pH}$ kritis sehingga dapat menyebabkan erosi pada gigi dan bahan tumpatan. ${ }^{21}$

Penelitian ini menunjukkan peningkatan nilai kekuatan tekan SIK tipe II untuk perendaman di dalam saliva buatan dan minuman isotonik. Berdasarkan uji post-hoc, terdapat perbedaan yang bermakna untuk kenaikan nilai kekuatan tekan antar kelompok tersebut. Berdasarkan penelitian sebelumnya diketahui bahwa SIK lebih mengalami kerusakan morfologis saat berada dalam suasana asam, jika dibandingkan dengan perendaman saliva dengan pH 7. Hal ini kemungkinan disebabkan oleh konsentrasi ion $\mathrm{H}^{+}$yang tinggi pada minuman isotonik dapat memutuskan ikatan ionik antara ion $\mathrm{Ca}^{+}$dan rantai karboksil (COO-) pada SIK tipe II, sedangkan pada saliva buatan dengan $\mathrm{pH} 7$ keadaannya lebih netral. Pada keadaan asam SIK tipe II berada pada $\mathrm{pH}$ kritis yaitu $\mathrm{pH} 4,5$, pelepasan ion fluor sangat sedikit, pada $\mathrm{pH}$ normal yaitu di dalam perendaman saliva buatan pelepasan fluor pada SIK meningkat. ${ }^{19}$

Pada penelitian yang dilakukan oleh Sugiyo menyatakan bahwa perendaman dalam minuman asam yang mengandung konsentrasi ion $\mathrm{H}^{+}$lebih tinggi dapat menimbulkan potensi lebih besar untuk berikatan dengan gugus karboksil yang disebabkan sifat nukleofilik (kemampuan untuk menangkap ion $\mathrm{H}^{+}$) gugus karboksi. Saliva dengan $\mathrm{pH}$ netral tidak mengalami ionisasi sempurna untuk menghasilkan ion $\mathrm{H}^{+}$dan $\mathrm{OH}^{-}$, sehingga tidak berpotensi berikatan dengan gugus karboksil. ${ }^{22}$
Perbedaan nilai kekuatan antara kelompok perendaman isotonik 24 jam dilanjutkan perendaman saliva buatan 72 jam dan kelompok perendaman isotonik 48 jam dilanjutkan perendaman saliva buatan 144 jam, menunjukkan peningkatan nilai kekuatan tekan yang bermakna. Hal ini kemungkinan disebabkan oleh semakin lama SIK tipe II berada dalam suasana netral maka semakin banyak fluor yang dihasilkan. Pada suasana asam terjadi pelepasan ion $\mathrm{Ca}^{+}$ SIK tipe II yang menyebabkan nilai kekuatan tekan menurun pada kelompok perendaman minuman isotonik. Pada perendaman saliva buatan yang mengandung $\mathrm{CaCl}_{2}$, ion $\mathrm{Ca}^{+}$berikatan kembali dengan SIK, semakin lama waktu perendaman dalam saliva buatan akan semakin banyak ion $\mathrm{Ca}^{+}$yang berikatan sehingga meningkatkan nilai kekuatan tekan SIK tipe II. ${ }^{23}$

Feejerkov dan Kidd menyatakan bahwa ketika pH mulut asam maka enzim bicarbonate anhydrase dalam saliva akan mengkatalis reaksi antara ion $\mathrm{H}^{+}$bebas dari dan ion bikarbonat. Reaksi tersebut menghasilkan air dan karbondioksida yang akan dilepas ke rongga mulut, sehingga $\mathrm{pH}$ saliva secara perlahan-lahan kembali ke $\mathrm{pH}$ normal dalam waktu kurang lebih 30-60 menit. Individu dengan aliran saliva yang rendah, maka kapasitas buffernya menurun dan rentan terhadap asam. Hal tersebut menyebabkan $\mathrm{pH}$ saliva akan membutuhkan waktu lebih dari 4 jam untuk perlahan-lahan kembali ke $\mathrm{pH}$ normal. ${ }^{24}$

Penelitian sebelumnya menunjukkan sejumlah restorasi sewarna gigi mengalami kenaikan nilai kekerasan permukaan setelah perendaman di dalam saliva. Pada penelitian ini SIK tipe II direndam terlebih dahulu di dalam minuman isotonik, baru setelah itu direndam dalam saliva buatan, ternyata minuman isotonik lebih mudah dinetralisir, sehingga peran saliva lebih dominan jika dibandingkan dengan minuman isotonik tersebut. Berkaitan dengan paparan asam yang minimal, setelah reaksi pengerasan SIK tipe II lebih mudah untuk terjadi kembali ikatan kimia. ${ }^{12}$

Mekanisme lain yang berpengaruh terhadap nilai kekuatan tekan SIK tipe II 
dalam penelitian ini adalah suhu pada saat penyimpanan spesimen SIK tipe II, lama waktu manipulasi, ratio powder dan liquid, bentuk serta kehalusan spesimen SIK tipe II, serta kemampuan pembilasan oleh saliva buatan. Akan tetapi, karena penelitian ini dilakukan secara in vitro, keadaannya berbeda dengan keadaan rongga mulut yang sebenarnya. $^{12,23}$

\section{SIMPULAN}

1. Terdapat pengaruh saliva buatan terhadap kekuatan tekan Semen Ionomer Kaca yang direndam dalam minuman isotonik, hal ini terlihat dari peningkatan nilai kekuatan tekan antara spesimen yang hanya direndam minuman isotonik dangen spesimen yang direndam minuman isotonik dan dilanjutkan dengan perendaman saliva buatan, yang berarti $\mathrm{H}_{1}$ diterima dan $\mathrm{H}_{0}$ ditolak.

2. Nilai kekuatan tekan paling tinggi yaitu SIK tipe II pada kelompok perendaman minuman isotonik dan dilanjutkan perendaman di dalam saliva buatan selama 144 jam. Sedangkan, nilai kekuatan tekan paling rendah adalah SIK tipe II pada kelompok perendaman minuman isotonik 24 jam.

\section{SARAN}

1. Dibutuhkan penelitian lebih lanjut tentang pengaruh saliva buatan terhadap kekuatan tekan Semen Ionomer Kaca yang direndam dalam minuman isotonik.

2. Minuman isotonik memiliki dampak buruk bagi kesehatan gigi, sebaiknya minimalisir konsumsi minuman tersebut.

\section{DAFTAR PUSTAKA}

1. Bresciani E, Barata T, Fagunsdes $T$, Adachi A, Terrin M, Navarro M. Compressive and diametral tensile strength of glass ionomer cements. Journal of Applied oral Science [seial online] 2004 oct-des.Available from: URL: http://www.scielo.br/scielo.php? script=sci_arttext $\&$ pid=S167875720040004 00017. Diakses 28 Maret 2014.

2. Noort R. Introduction to dental Materials, 4th ed. China: Elsevier Mosby; 2013. p. 95.

3. Walmsley A, Walsh T, Lumley P, Burke F, Shortall A, Hall R, et al. Restorative dentistry, 2th ed. British : Churchil Livingstone; 2007. p. 80-1.

4. Hussain S. Text book of Dental Materials. India: Jaype Brother medical Publisher; 2004.p. 2.

5. Nagaraja U, Kishore G. Glass Ionomer Cement - The Different Generations. Trends Biomater. Artif. Organ J Jan 2005; 18 (2);158-65.

6. Melzarini A, Irmawati. Kekerasan permukaan semen ionomer kaca konvensional tipe II akibat lama penyimpanan. Maj ked. Gigi (Dent J) julsept 2005; 38(3): 146-9.

7. Hassan U, Farooq I, Mahdi S, Ullah R, Rana $\mathrm{H}$. Newer Glass Ionomer Cement having Strontium ions and the Effect of their Release on Acid Medium. International Journal of Prosthodontics and restorative Dentistry, April-June 2012; 2(2): 57-60.

8. Singh M, Suresh P, Sandhyarani J, Sravanti. Glass Ionomer Cements (GIC) In Dentistry: A Review. International Journal Of Plant, Animal And Environmental Sciences March-May 2011; 1(1): 22-30.

9. Mousavinasab MS, Meyers I. Flouride Release by Glass Ionomer Cement, Compomer, and Giomer. Dent Res J JulNov 2009; 6(2): 75-81.

10. Morand JM, Jonas P. Resin-modifed glassionomer cement restoration of posterior teeth with proximal carious lesion. Quintessence Int J 1995; 26(6): 389-94.

11. Quader A, Alam S, Bashar M, Gafur A, AlMansur A. Compressive Strength, Fluoride Release and Recharge of Giomer. Updat Dent. Coll .j 2012; 2(2): 28-37.

12. Drake I. Sports drink growth gathers pace as new launches drive sales. Australian Food News. [serial online] 2008. Available from: http://www.ausfoodnews.com.au/2008/12/1 2/ sports-drink-growth-gathers-pace-as-newlaunches-drive-sales.html. Diakses 28 Maret 2014.

13. Saputri O, Zala Q, Arnanda B, Ardhani R. Saliva as an Early Detection Tool for Choronic Obstructive Pulmonary Disease Risk in Patients with Periodontitis. Journal of Dentistry Indonesia 2010; 17( 3): 87-92. 
14. Puy C. The role of saliva in maintaining oral health and as an aid diagnosis. Med Oral Patol Oral Cir Bucal 2006; 11(5): 449-55.

15. Putriyanti F, Herda E, Soufyan A. Pengaruh saliva buatan terhadap diametral tensile strength micro fine hybrid resin composite yang direndam dalam minuman isotonic. Jurnal PDGI 2012 jan-april ; 61(1): 43-7.

16. Ramadhani SF. Kelarutan Fosfat Email Pada Perendaman Gigi Dalam Minuman Isotonik dan Asam Folat. FKG Unhas. Makassar, 2013. h.39. Skripsi.

17. Toledano M., Osorio R., Osorio E., Fuentes V., Prati C., Garcia-Godoy F.,2003, Sorption and Solubility of Resin Based Restorative Dental Materials, J of Dentistry, 31:43-50.

18. Wulandari P. 2005, Pengaruh Lama Perendaman SIK Tipe I dalam Saliva pH 5 Terhadap Kekuatan Geser (Penelitian Laboratoris). FKG UI,Jakarta, h.23-24. Skripsi.

19. Anusasavice KJ. Buku Ajar Bahan Kedokteran Gigi, 10 th ed. Jakarta: EGC; 200. p.48, 464.
20. Patel, Sabikhi L, Kumar S, Khetra Y. Innovative trends in dairy and food products formulation. India: National Dairy Research Institute; 2012, p.5-6.

21. Mettler S, Rusch C, Colombani PC. Osmolality and $\mathrm{pH}$ of sport and other drinks available in Switzerland, Sportmedizin und Sporttraumatologie; 2006: 54(3): 92-5.

22. Sugiyo P. Pengaruh Perendaman dan Derajat Keasaman Saliva Terhadap Perubahan Warna Pada Basis Gigi Tiruan Lepasan dengan Thermoplastyc Nylon. FKG UGM, Yogyakarta, 2013. h.38,40. Tesis.

23. Santoso PT. Kekerasan permukaan email setelah aplikasi gel karbamid peroksida 10\% dan pasta buah strawberry. Dentofasial J 2009;8(2):118-24.

24. Fejerskov O., Kidd E. Dental Caries: The Disease and Its Clinical Management, Blackwell Munksgand, Oxford, 2003. h.196395. 